\title{
ANALISIS KESULITAN BELAJAR MATEMATIKA PADA ANAK USIA DINI (TINGKAT PRA SEKOLAH/TK) DAN ALTERNATIF PEMECAHANNYA
}

\author{
Rahmad Bustanul Anwar \\ Universitas Muhammadiyah Metro \\ E-mail: rarachmadia@gmail.com
}

\begin{abstract}
Intisari : Pendidikan anak usia dini adalah suatu upaya pembinaan yang ditujukan kepada anak sejak lahir sampai dengan usia enam tahun yang dilakukan melalui pemberian rangsangan pendidikan untuk membantu pertumbuhan dan perkembangan jasmani dan rohani agar anak memiliki kesiapan dalam memasuki pendidikan lebih lanjut. Hasil penelitian yang dilaksanakan menunjukkan bahwa subyek tidak mengalami kesulitan untuk menyelesaikan operasi perhitungan penjumlahan dalam bentuk gambar dan angka, sedangkan untuk pengurangan mengalami kesalahan perhitungan. Tetapi untuk penyelesaian soal penjumlahan dan pengurangan dalam bentuk soal cerita, subyek belum mampu menyelesaikannya. Hal tersebut dikarenakan subyek belum mampu memaknai isi dari soal yang diberikan. Untuk mengatasi permasalahan tersebut, alternatif yang diberikan pada saat penelitian adalah memberikan bimbingan untuk memaknai isi dari soal yang diberikan, setelah subyek dapat memaknai isi dari soal kemudian subyek diminta untuk menyelesaikan soal tersebut.

Kata Kunci: Kesulitan Belajar Matematika, Anak Usia Dini.
\end{abstract}

\section{PENDAHULUAN}

Matematika adalah suatu pengetahuan yang mampu mengembangkan kemampuan berpikir anak. Oleh sebab itu matematika dapat sebagai sarana untuk membangun kemampuan berpikir anak mulai dari usia dini, usia pendidikan kelas awal (pendidikan dasar), pendidikan menengah, pendidikan lajutan dan bahkan sampai mereka berada di bangku perkuliahan.

Undang-Undang Sistem Pendidikan Nasional dalam pasal 1 menegaskan bahwa, pendidikan anak usia dini adalah suatu upaya pembinaan yang ditujukan kepada anak sejak lahir sampai dengan usia enam tahun yang dilakukan melalui pemberian rangsangan pendidikan untuk membantu pertumbuhan dan perkembangan jasmani dan rohani agar anak memiliki kesiapan dalam memasuki pendidikan lebih lanjut. 
Masa kanak-kanak awal (usia 3 - 6 tahun) sering disebut masa pra sekolah, tetapi pada saat ini telah banyak sekali dikembangkan model-model sekolah untuk anak pada masa ini diantaranya adalah TK (Taman Kanak-Kanak). Saat ini, anak usia dini di Indonesia jumlahnya puluhan juta jiwa. Anak usia 0 - 4 tahun berjumlah 19.591.740 jiwa (laki-laki 9.983.140; perempuan 9.608.600) dan anak usia 5 - 9 tahun berjumlah 22.109.704 jiwa (laki-laki 11.370.615; perempuan 10.739.089). Penanganan anak usia dini secara baik akan sangat menentukan mutu sumber daya produktif kita dua puluh tahun mendatang (SUPAS dalam Prastiwi :2008).

Khusus untuk masa kanak-kanak awal atau masa pra sekolah, matematika sangat berguna sekali bagi mereka untuk mengembangkan proses berpikir. Pembelajaran matematika yang diberikan pada tingkat anak usia dini masih bersifat non formal, dimana anak belum sepenuhnya diberikan materi matematika yang sebenarnya tetapi baru bersifat pengenalan. Pada pendidikan matematika dapat diberikan misalnya pada pengenalan bilangan, terlebih dahulu diperdengarkan angka dengan menyebutkan angka satu, dua, tiga dan seterusnya. Dan perlihatkan benda-benda berjumlah satu, dua, tiga dan seterusnya, bukan berarti materinya langsung mengenalkan lambang bilangan "dua" karena anak akan bingung. Dengan bertambahnya kecerdasan dan umur barulah diperkenalkan ke lambang bilangan.

Pembelajaran matematika merupakan cabang mata pelajaran yang cakupannya sangat luas dan bukan hanya bisa berhitung tetapi juga mencakup kompetensi yang menjadikan anak tersebut memahami dan mengerti tentang konsep matematika. Untuk pendidikan matematika dapat diberikan pada anak tingkat usia dini dengan metode learning by playing atau belajar sambil bermain, karena waktu bermain anak akan mendapat kesempatan bereksplorasi, bereksperimen dan dengan bebas mengekspresikan dirinya. Dengan bermain, tanpa sengaja anak akan memahami konsep-konsep matematika tertentu dan melihat adanya hubungan antara satu benda dan yang lainnya.

Djauhari dalam Wiguna mengemukakan: "Lemahnya pendidikan matematika di Indonesia merupakan akibat tidak diajarkannya filsafat atau latar belakang ilmu matematika. Dampaknya siswa pandai mengerjakan soal, tetapi tidak bisa memberikan makna dari soal itu. Matematika hanya diartikan sebagai persoalan hitung-hitungan yang siap untuk diselesaikan atau dicari jawabannya".

Pada usia pra sekolah anak sudah dikenalkan operasi dasar bilangan matematika. Diantaranya yang sangat familiar pada usia pra sekolah adalah operasi matematika penjumlahan dan pengurangan. Untuk dapat mengenalkan operasi dasar matematika pada tingkat anak usia dini tidaklah mudah, dibutuhkan banyak metode-metode agar anak dapat dengan mudah untuk menerima dan memahami makna dari operasi yang sedang dilaksanakan. Diantaranya melakukan operasi penjumlahan dan pengurangan dengan menggunakan benda-benda yang ada disekitar, misalnya pengenalan penjumlahan dan pengurangan, dengan memakai lima bola berdiameter sama yang dapat digenggam. Untuk pengurangan, sebanyak lima bola diambil satu, dua, ..., dan lima. Sebaliknya penjumlahan dengan menambahkan satu, dua, ..., sampai empat pada bola yang tergenggam. Mengingat ciri khas pada setiap jumlah bola yang sering dilihatnya, anak pun akan melihat kejanggalan ketika dikurangi atau ditambah. 
\begin{tabular}{l|l} 
Rahmad Bustanul Anwar & 65
\end{tabular}

Peristiwa tersebut membuatnya semakin memahami hakikat "bertambah" dan "berkurang", yang ditandai perubahan jumlah bola yang digenggamnya. Apalagi pada peragaan bola yang diameter dan warnanya beragam, pemahamannya tidak lagi terikat dengan ukuran, tetapi pada jumlah bola yang tampak.

Banyak sekali usaha yang dilakukan oleh orang tua atau pendidik pada tingkat TK untuk mengenalkan operasi penjumlahan atau pengurangan. Diantaranya anak diminta untuk mengoperasikan penjumlahan atau penguranan dengan menggunakan gambar. Dari gambar tersebut anak diminta untuk menerjemahkan kedalam bentuk angka dan mengoperasikannya.

Selain ilmu matematika pada usia anak pra sekolah/TK, anak juga sudah didikenalkan dengan huruf-huruf alfabet dimana tujuannya supaya anak mampu mengenal dan menggunakannya dalam membaca. Berbagai metode mengajar dipraktikkan, dengan harapan bisa membantu anak-anak untuk menguasai keterampilan membaca dan menulis sebelum masuk sekolah dasar. Beberapa anak mungkin berhasil menguasai keterampilan tersebut, namun banyak pula di antaranya yang masih mengalami kesulitan. Kunci bagi kemampuan baca yang fasih adalah proses otomatisasi, yakni pemerolehan arti kata tanpa melakukan usaha (otomatis).

Jean Piaget (dalam Montessori: 2008)mengemukakan bahwa pelajaran membaca, menulis, dan berhitung secara tidak langsung dilarang untuk diperkenalkan pada anak-anak di bawah usia 7 tahun. Piaget beranggapan bahwa pada usia di bawah 7 tahun anak belum mencapai fase operasional konkret. Fase itu adalah fase, di mana anak-anak dianggap sudah bisa berpikir terstruktur. Sementara itu, kegiatan belajar calistung sendiri didefinisikan sebagai kegiatan yang memerlukan cara berpikir terstruktur, sehingga tidak cocok diajarkan kepada anak-anak TK yang masih berusia balita.

Sedangkan Montessori: 2008 mengatakan bahwa pada usia 3-5 tahun, anak-anak dapat diajari menulis, membaca, dikte dengan belajar mengetik. Sambil belajar mengetik anak-anak belajar mengeja, menulis dan membaca. Ada suatu penelitian di Amerika yang menyimpulkan bahwa kenyataannya anakanak dapat belajar membaca sebelum usia 6 tahun. Hasil penelitian ini menunjukkan bahwa ada sekitar 2 $\%$ anak yang sudah belajar dan mampu membaca pada usia 3 tahun, $6 \%$ pada usia empat tahun, dan sekitar $20 \%$ pada usia 5 tahun. Bahkan terbukti bahwa pengalaman belajar di taman kanak-kanak dengan kemampuan membaca memadai akan sangat menunjang kemampuan belajar pada tahun-tahun berikutnya.

Kegiatan belajar anak usia dini/TK lebih mengacu pada kegiatan bermain sambil belajar, sedangkan pendidikan untuk tingkat usia dini/TK yang berkembang saat ini difungsikan untuk mempersiapkan anak untuk memasuki masa sekolah yang dimulai dari tingkat sekolah dasar. Akan tetapi pada kenyataanya tidak sedikit anak yang tidak dapat mengikuti pelajaran yang diberikan di tingkat sekolah dasar terutama untuk kegiatan membaca, menulis dan berhitung. Sehingga kegiatan belajar yang berkembang di tingkat TK mendesain kegiatan belajar yang mengacu pada materi belajar tingkat sekolah dasar. 


\section{DESKRIPSI SUBYEK, ANALISIS DATA DAN PEMBAHASAN}

\section{A. Deskripsi Subyek}

Pada pelaksanaan penelitian ini, peneliti mengambil subyek seorang anak yang mempunyai identitas diri sebagai berikut:

$\begin{array}{ll}\text { Nama } & \text { : Sofieatul Latifah } \\ \text { Usia } & : 5 \text { tahun } 9 \text { bulan } \\ \text { Pendidikan } & : \text { TK kelas B } \\ \text { Status dalam keluarga } & : \text { Anak pertama } \\ \text { Pekerjaan orang tua } & \text { : Dagang } \\ \text { Motivasi belajar dari orang tua } & : \text { Sangat baik }\end{array}$

Tingkat kemampuan yang dimiliki subyek dalam kategori tinggi, hal tersebut dapat dilihat bahwa subyek telah mampu mengenal simbol angka dan mengoperasikan dengan operasi dasar matematika dengan baik selain itu subyek juga telah dapat membaca dengan baik.

\section{B. Analisis Data}

Dalam penelitian ini peneliti memberikan 6 buah soal yang terdiri dari 3 buah kategori:

1. Operasi penjumlahan dari gambar yaitu soal nomor 1 dan 2.

2. Operasi penjumlahan dan pengurangan dalam bentuk angka yaitu soal nomor 3 dan 4 .

3. Operasi penjumlahan dan pengurangan dalam bentuk soal cerita yaitu soal nomor 5 dan 6 .

Adapaun lambang yang digunakan dalam analisis data ini pada hasil wawancara yaitu:

(R) : : Lambang untuk percakapan peneliti (Rahmad)

(S) : : Lambang untuk percakapan subjek penelitian (Sofie).

Sedangkan waktu yang diberikan untuk menyelesaikan soal tersebut adalah 15 menit.

Berikut analisis data dari hasil jawaban subjek yang diperoleh:

\section{Soal 1.}

Perhatikan gambar berikut:

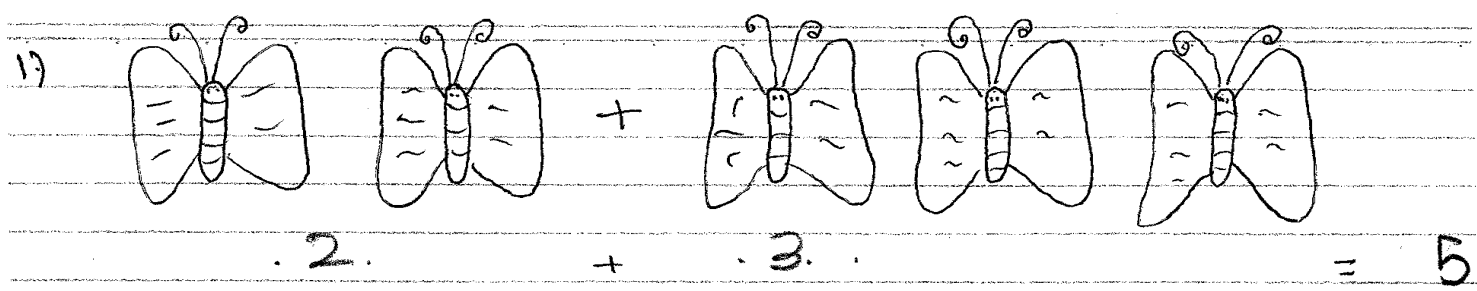

Dari soal di atas peneliti ingin mengetahuai kemampuan Sofie pada operasi penjumlahan dua buah bilangan yang berasal dari gambar. 


\section{Hasil wawancara:}

(R) : Apakah kamu paham dari soal ini?

(S) : Paham, ini kan Cuma menjumlahkan kupu-kupu.

(R) : Bagus. Coba sekarang di jumlahkan.

(S) : Dua kupu-kupu di tambah tiga kupu-kupu. (Sofie beraksi dengan menggerakkan jari-jarinya untuk menjumlahkan bilangan tersebut).

(S) : Lima kupu-kupu.

(R) : Pinter.

Analisis hasil penelitian:

Pada operasi penjumlahan di atas Sofie tidak mengalami kesulitan atau tidak ada masalah untuk menyelesaikan soal yang di ajukan.

Soal 2.

Perhatikan gambar berikut:

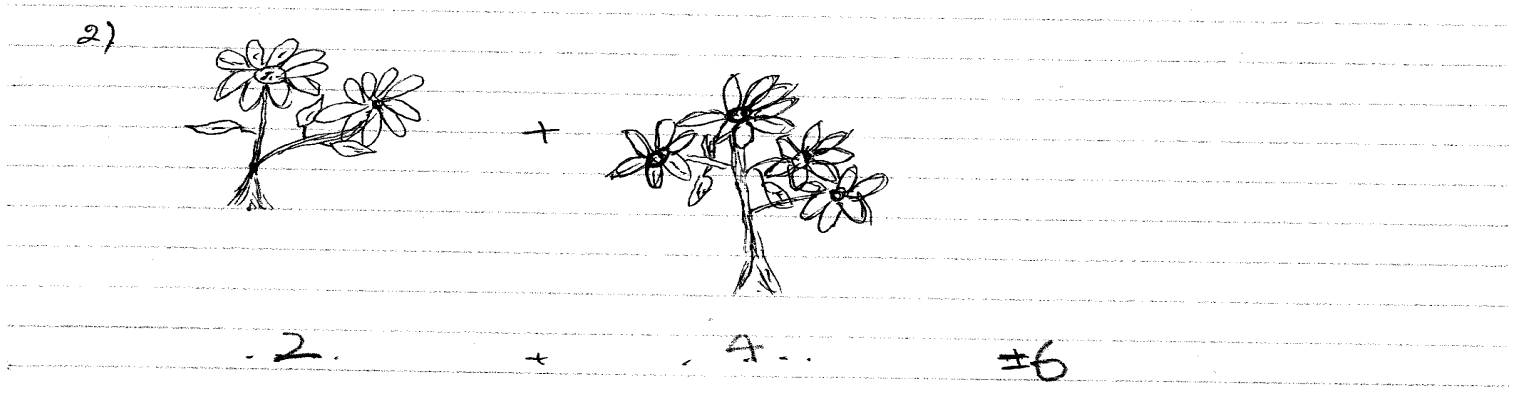

Darı soal dı atas penelıtı ıngın mengetahuaı kemampuan Sotıe pada operası penjumlanan dua buah bilangan yang berasal dari gambar.

\section{Hasil wawancara:}

(R) : Apakah kamu paham dari soal ini?

(S) : Paham, menjumlahkan bunga dari pohon.

(R) : Bagus. Coba sekarang di jumlahkan.

(S) : Dua bunga ditambah empat bunga.. (Sofie beraksi dengan menggerakkan jari-jarinya untuk menjumlahkan bilangan tersebut).

(S) : Enam bunga.

(R) : Pinter.

Analisis hasil penelitian:

Berdasarkan hasil penelitian dari soal nomor 1 dan 2 yaitu tentang penjulahan dua buah bilangan dari gambar, subyek sudah dapat menyelesaikan dengan benar. Hal tersebut dapat menunjukkan bahwa subyek telah memahami konsep dan operasi bilangan dari gambar.

\section{Soal 3.}

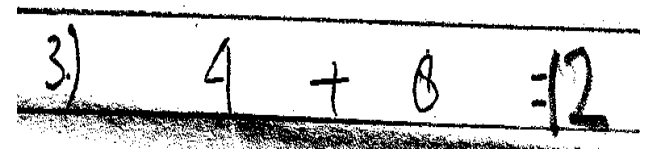


Dari soal di atas peneliti ingin mengetahuai kemampuan Sofie pada operasi penjumlahan dua buah bilangan dengan menggunakan angka.

\section{Hasil wawancara:}

(R) : Apakah kamu paham dari soal ini?

(S) : Paham, ini tambah-tambahan empat di tambah delapan.

(R) : Bagus. Coba sekarang di jumlahkan.

(S) : (lagi-lagi Sofie beraksi dengan jari-jarinya yaitu dengan mengingat angka empat kemudian dengan menggunakan jari-jari melanjutkan hitungan sebanyak 8 tekukan jari) Jawabnya: dua belas.

(R) : Pinter.

Analisis hasil penelitian:

Pada operasi penjumlahan dua buah bilangan di atas Sofie tidak mengalami kesulitan atau tidak ada masalah untuk menyelesaikan soal yang diberikan.

Soal 4.

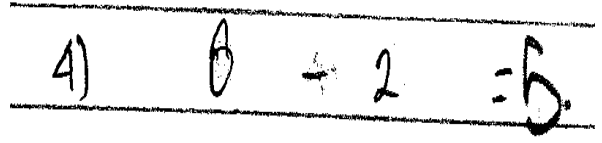

Dari soal di atas peneliti ingin mengetahuai kemampuan Sofie pada operasi pengurangan dua buah bilangan dengan menggunakan angka.

\section{Hasil wawancara:}

(R) : Apakah kamu paham dari soal ini?

(S) : Paham, pengurangan delapan dikurang dua

(R) : Bagus. Coba sekarang di jumlahkan.

(S) : (Sofie beraksi dengan jari-jarinya yaitu dengan merentangkan 8 jari-jari kemudia dikurang 2, sofie menekuk 2 jari-jari dan menghitungnya) Jawabnya: enam.

(R) : ko' ini jawabanya lima?

(S) : ya salahh (sambil tertawa kecil)

Analisis hasil penelitian:

Pada penyelesaian soal operasi pengurangan di atas Sofie mengalami kesalahan perhitungan pada perhitungan yang pertama yaitu lupa tidak menghitung 1 jari-jari, tetapi untuk operasi pengurangan Sofie sudah memahaminya. 


\section{Soal 5.}

Perhatikan soal berikut:

\section{3) Aba Lima ekor sapi ditambah tiga etor sapi, berapa jumlah semuanya?}

Dari soal di atas peneliti ingin mengetahuai kemampuan Sofie pada operasi penjumlahan dua buah bilangan dari soal cerita. Tetapi Sofie tidak dapat menjawab soal yang diberikan.

\section{Hasil wawancara:}

(R) : Coba sekarang ini dibaca soal ini?(Peneliti menunjuk soal nomor 5).

(S) : (Membaca soal dengan lancar walaupun dengan intonasi yang naik turun).

(R) : Bagus. Sofie paham yang baru kamu baca?

(S) : (diam agak lama dan tidak menjawab)

(R) : (membacakan soal) kemudian menjelaskannya "Ada Lima ekor sapi ditambah tiga ekor sapi, berapa jumlahnya?"

(S) : (Sofie menjawab)Oo..sapinya ditambah. "Lima sapi ditambah tiga sapi". Jawabnya "delapan sapi".

(R) : pinter

Analisis hasil penelitian:

Pada operasi penjumlahan dalam bentuk soal cerita di atas Sofie mengalami kesulitan untuk memahami soal pada saat membaca, tetapi dapat menjawabnya dengan benar setelah diberikan penjelasan.

\section{Perbaikan:}

Soal perbaikan:

5. Di dalam kandang ada Lima ekor sapi, kemudian masuk tiga ekor sapi lagi. Berapa jumlah sapi di dalam kandang sekarang?

Hasil penelitian:

Setelah soal diperbaiki, soal diberikan lagi kepada Sofie untuk mengerjakan lagi. Hasil yang diperoleh juga sama dengan penelitian sebelumnya yaitu Sofie hanya mampu membaca soal tetapi belum mampu untuk menjawab soal walaupun pada soal sebelumnya sudah diberikan penjelasan tetapi dengan soal yang hanya berbeda dalam bahasa dan maknanya sama Sofie belum mampu untuk menjawab soal.

\section{Soal 6.}

6) Ada sembilan ekor burung kemuoian lima ekor burung pergi terbang, berapa jumlah burung sekarang? bilangan dari soal cerita. Tetapi Sofie tidak dapat menjawab soal yang diberikan.

\section{Hasil wawancara:}

(R) : Coba sekarang ini dibaca soal ini?(Peneliti menunjuk soal nomor 6). 
(S) : (Membaca soal dengan lancar walaupun dengan intonasi yang naik turun).

(R) : Sofie paham yang baru kamu baca?

(S) : (Tidak menjawab)

(R) : (membacakan soal) kemudian menjelaskannya bahwa "Ada sembilan ekor burung kemudian lima ekor pergi terbang, berapa jumlahnya?"

(R) : Berarti burungya ditamhakan atau dikurang?

(S) : Dikurang. (Sofie sudah memahami maksud soal).

(R) : Sekarang dihitung berapa jumlah burungnya.

(S) : (Menghitung dengan merentangkan jari-jari sebangyak 9 jari-jari kemudian menekuk 5 jari-jari yang bermaksud untuk mengurang) Jawabanya empat burung.

(R) : Benar.

Analisis hasil penelitian:

Pada soal no 6 ini yaitu tentang operasi pengurangan dalam bentuk soal cerita di atas, Sofie mengalami kesulitan sama dengan soal no 5 yaitu kesulitan memahami soal pada saat membaca, tetapi dapat menjawabnya dengan benar setelah diberikan penjelasan.

\section{Pembahasan}

\section{Analisa kesulitan menerjemahkan operasi penjumlahan dari gambar.}

Dalam penelitian ini soal yang berupa operasi penjumlahan dengan menggunakan gambar terdiri dari dua buah nomor soal yaitu nomor 1 dan 2. Dari hasil penelitian diperoleh subyek mampu menyelesaikan soal dengan benar. Berarti bahwa subyek telah memahami konsep operasi dari soal yang diberikan dan tidak mengalami kesulitan untuk menyelesaikan operasi penjumlahan yang diminta.

\section{Analisa kesulitan operasi penjumlahan dan pengurangan dua buah bilangan.}

Dari hasil penelitian diperoleh bahwa subyek tidak mengalami kesulitan untuk memecahkan masalah dalam bentuk operasi penjumlahan dan pengurangan dua buah bilangan yang terdapat dalam nomor 3 dan 4. Data yang diperoleh subyek hanya melakukan kesalahan pada saat perhitungan pada operasi pengurangan yaitu lupa tidak menghitung 1 jari-jarinya.

\section{Analisa kesulitan operasi penjumlahan dan pengurangan dalam bentuk soal cerita.}

Pada saat dilaksanakan penelitian subyek telah mampu membaca dengan baik walau dengan intonasi nada yang naik turun. Tetapi subyek belum mampu memahami isi dari soal yang dibacanya. Sehingga subyek tidak dapat menjawab soal yang diberikan.

\section{Alternatif Pemecahan Masalah}

Dari hasil penelitian yang diperoleh tampak jelas bahwa subyek hanya mengalami kesulitan pada kategori memecahkan masalah dalam bentuk soal cerita yang diberikan. Hal itu dikarenakan subyek belum mampu memaknai isi dari soal yang dibacanya walaupun subyek sudah dapat membaca. 
Rahmad Bustanul Anwar $\mid 71$

Permasalahan tersebut sesuai dengan teori yang di kembangkan oleh Piaget bahwa anak belum mencapai fase operasional konkret. Fase itu adalah fase, di mana anak-anak dianggap sudah bisa berpikir terstruktur. Sementara itu, kegiatan belajar membaca, menulis dan berhitung sendiri didefinisikan sebagai kegiatan yang memerlukan cara berpikir terstruktur, sehingga tidak cocok diajarkan kepada anakanak TK.

Pada saat dilakukan wawancara ternyata subyek dapat menjawab dengan benar setelah peneliti memberikan bimbingan untuk memaknai isi dari soal cerita tersebut. Untuk itu alternatif yang dapat diberikan untuk mengatasi kesulitan subyek dalam memahami isi dari soal yang berupa soal cerita dibutuhkan pendekatan dan metode-metode yang menarik dan mudah diterima anak misalnya dengan menggunakan media seperti benda-benda yang ada disekitar sehingga anak dapat dengan mudah memahami maksud dari soal dan selain itu tingkat bahasa soal juga harus disesuaikan dengan kondisi anak (komunikatif).

\section{KESIMPULAN DAN SARAN}

\section{A. Kesimpulan}

Berdasarkan hasil penelitian yang dilaksanakan menunjukkan bahwa subyek tidak mengalami kesulitan untuk menyelesaikan operasi perhitungan penjumlahan dalam bentuk gambar dan angka, sedangkan untuk pengurangan mengalami kesalahan perhitungan. Tetapi untuk penyelesaian soal penjumlahan dan pengurangan dalam bentuk soal cerita, subyek belum mampu menyelesaikannya. Hal tersebut dikarenakan subyek belum mampu memaknai isi dari soal yang diberikan. Untuk mengatasi permasalahan tersebut, alternatif yang diberikan pada saat penelitian adalah memberikan bimbingan untuk memaknai isi dari soal yang diberikan, setelah subyek dapat memaknai isi dari soal kemudian subyek diminta untuk menyelesaikan soal tersebut.

\section{B. Saran}

Anak pada tingkat usia dini/TK sangat membutuhkan bimbingan dalam belajar, untuk itu penulis memberikan saran kepada:

\section{Orang tua}

Diharapkan orang tua dapat memberikan bimbingan, motivasi kepada anak terhadap khususnya materi matematika yang ajarkan. Pengaruh orang tua sebagai pada anak memiliki porsi terbesar dilingkungannya, sehingga orang tua dalam mendidik anak dengan membawa mereka sambil bermain dan orang tua dapat memancing anak untuk memunculkan ide kreatif dan inovatifnya.

2. Guru

Guru merupakan figur yang sering dianut oleh anak, sehingga guru diharapkan mampu menciptakan suasana pembelajaran yang kreatif dan menarik minat anak untuk mengikuti proses belajar. 
72 Analisis Kesulitan Belajar Matematika

\section{DAFTAR PUSTAKA}

Montessori, Maria. 2008. The Absorbent Mind (Pikiran yang Mudah Menyerap). Yogyakarta: Pustaka Pelajar.

Prastiwi, Dinar Wiwien. Psikologi Anak Usia Dini. 2008. Surakarta.

Wiguna, Tjhin .2003. Seluk Beluk Kesulitan Belajar Pada Anak. Didapatkan 12 Juni 2010 dari http://groups.yahoo.com/group/cfbe/message/5531

UUD RI NO 20 TAHUN 2003 tentang SISDIKNAS PASAL 1 